\title{
Peanut Pods (Arachis hypogaea L.) In Ex-Mining Limestone Soil Enriched with Indigenous Bacteria
}

\author{
Riska Andriani $^{1 *}$, Hesti Kurniahu ${ }^{2}$, Sriwulan $^{3}$, Annisa Rahmawati ${ }^{4}$ \\ ${ }^{124}$ Biology Study Program, Faculty MIPA, Universitas PGRI Ronggolawe Tuban, Indonesia \\ ${ }^{3}$ Biology Education Study Program, FKIP, Universitas PGRI Ronggolawe Tuban, Indonesia \\ *email: andrianilriska@gmail.com
}

\begin{tabular}{l} 
Article Info \\
\hline Keyword: \\
Pods \\
Pioneer plants \\
Indigenous PGPR \\
Peanuts \\
Limestone quarry
\end{tabular}

\section{Article history:}

Received: $27 / 11 / 2020$

Revised: $31 / 12 / 2020$

Accepted: 06/01/2021

\begin{abstract}
Pioneer plants are found in the former limestone mining area, and there are bacteria in their root systems. These bacteria can be used as biofertilizers. This study aims to find out the use of indigenous PGPR in ex-mining limestone land to be able to increase the yield of pea (Arachis hypogaea L.) var. Tuban. This research was an experimental study with 5 treatments applying indigenous PGPR at concentrations of $0 \%, 25 \%, 50 \%, 75 \%$, and $100 \%$ and consist of 5 replications. Stages of research include planting peanuts (Arachis hypogaea L.) var. Tuban by adding indigenous PGPR with the same dose and source in an environment with sufficient sunlight. The parameters observed were biomass, pithy weight, empty pod weight, wet weight, dry weight, $p H$, and temperature of the planting medium for peanuts. In this study, the results showed that the concentration of PGPR 25\% had a significant effect on the dry weight of peanuts and didn't have a significant effect on biomass. Meanwhile, the provision of PGPR with different concentrations did not have a significant effect on the temperature and $\mathrm{pH}$ of the lime mining soil planting media.
\end{abstract}

Copyright () 2021 The Author(s). All Right Reserved

\section{Introduction}

Fertilizer plays a role in increasing agricultural production because it can increase the number of soil nutrients that are useful for plant life. However, the continuous use of chemical fertilizers will increase the concentration of pollutants on the soil surface which causes a reduction in soil organic content, and a decrease in the biodiversity of fauna and soil microbes. The use of biological organic fertilizers by utilizing indigenous PGPR from pioneer plants can be used as an alternative to reduce the toxicity of chemicals in the agricultural environment (Hanudin et al., 2018).

The Pioneer plants have an adaptability toward environmental changes from their natural conditions, such as in post-lime mining land communities. The disturbance communities tend to have a higher index of plant diversity compared to stable and non disturbance communities (Andriani et al., 2019). One of the reasons is that these pioneer plants are associated with a group of bacteria found in plant roots called Plant Growth Promoting 
Rhizobacteria (PGPR) (Prayudyaningsih et al., 2015). This PGPR group of bacteria can produce phytohormones, mobilize nutrients, and control pathogens (Kurniahu, 2017). This PGPR group of bacteria can produce phytohormones, mobilize nutrients, and control pathogens (Kurniahu et al., 2018). In spurring plant growth, PGPR plays a role in providing absorbed nutrients for plants and producing hormones for plants as well as producing secondary metabolites which can be used as antagonisms to pests and plant diseases. Microbes have various abilities in self adaptation to carry out their ecological functions, so that the indigenous bacteria is needed (Aryanto, 2015).

Beside of suitable microbe application, the selection of suitable plants for cultivation in unfavorable environments such as nutrient-poor and dry conditions on calcareous soils was also required. Peanut (A. hypogaea L.) var. Tuban is one of the various types of plants that have adaptation characteristics in dry and poor nutrients soil condition, such as on calcareous land (Kasno \& Harnowo, 2015; Prayudyaningsih \& Sari, 2016). Peanut (A. hypogaea L.) cultivated on lime soil which is poor in nutrients requires the addition of fertilizers to increase yields (Wijanarko \& Rahmianna, 2015). The dependence of calcareous soil areas on chemical fertilizers has a negative impact on the environment including contamination of groundwater (Wuryanta, 2019). Therefore, an alternative biological organic fertilizer which has the adaptability on unfavorable environment and can increase crop yields, such as peanuts (A. hypogaea L.) var. Tuban is needed.

The use of PGPR pioneer plants from lime mining was reported to increase the growth of peanuts by 12 WAP (Week After Planting) in shady conditions (Sriwulan et al., 2018) and spur the growth of peanut plants for 6 WAP with the observed parameters. in the form of plant height, number of leaves, and leaf color (Kurniahu et al., 2018). However, research on the application of PGPR pioneer plants from limestone mining to the yield of peanut pods (A. hypogaea L.) var. Tuban has never been done. This study aims to know the effectiveness of the PGPR application of lime mining plants as biological organic fertilizer to increase the yield of peanut (A. hypogaea L.) var. Tuban in karst land.

\section{Materials and Methods \\ Tools and Materials Used}

The tools and materials used include beaker glass, scale, ruler, mortar and pestle, soil tester, measuring cup, the seeds of peanut (A. hypogaea L.) var. Tuban, polybags, root-soil of pioneer plants that live in the land around exmining limestone (Tridax procumbens, Crotalaria sp. Mimosa pudica, Imperata cylindrica, and Pteridophyta), ex-mining lime soil, phosphate buffer solution 0.01 $\mathrm{M}$ ( $\mathrm{pH}$ 7), and distilled water.

\section{Research procedure}

PGPR solution were obtained using the method based on Kurniahu et al. (2018) by taking 5 sample points which each from the roots of pioneer plants (Pteris vittata, Imperata cylindrica, Zea mays, and Pennisetum purpureum) that grew in the land around the former limestone mine. $100 \mathrm{~g}$, in the form of plant roots and surrounding soil. Furthermore, the sample maceration using mortar and pestle. Dilution the sample with 2.5 liters of $0.01 \mathrm{M}$ phosphate solution (pH 7) as a buffer and let stand for 1 week.

Two Seeds of Peanut (A. hypogaea L.) var. Tuban were planted in polybags that contained $5 \mathrm{~kg}$ of calcareous soil planting media. The seeds were planted in 1-2 cm depth. After 7 DAP (Days After 
Planting), the plants with the same growth were treated with $100 \mathrm{ml}$ of PGPR according to the dosage $(0 \%, 25 \%, 50 \%$, $75 \%$, and $100 \%$ ) every month on each plant. Observation of pods was carried out after 12 WAP (Weeks After Planting) by observing the total number of pods, the number of pithy pods, the weight of pithy pods, the number of empty pods, and the weight of empty pods.

\section{Analysis and Interpretation}

Data were analyzed using Manova test and the post hoc test using Bonferroni test if the data was homogeneous and the Games-Howell test if the data were not homogeneous to determine which treatments had significant differences.

\section{Results and Discussion}

In this study, the data were the weight of pithy pods, number of pods, the weight of empty pods, number of empty pods of peanuts (A. hypogaea L.) var. Tuban that has been observed after 12 WAP is listed in Table 1.

Table 1. The Effect of Indigen PGPR Application on Peanut Pods (A. hypogaea L.) var. Tuban.

\begin{tabular}{|c|c|c|c|c|c|}
\hline Treatment & Dry Weight & $\begin{array}{c}\text { Weight of } \\
\text { Bernas Pods }\end{array}$ & $\begin{array}{c}\text { Weight of } \\
\text { Empty Pods }\end{array}$ & $\begin{array}{l}\text { Amount of } \\
\text { Bernas Pods }\end{array}$ & $\begin{array}{c}\text { Amount of } \\
\text { Empty } \\
\text { Pods }\end{array}$ \\
\hline $0 \%$ & $25.54^{\mathrm{a}}$ & $12.82^{\mathrm{a}}$ & $5.50^{\mathrm{a}}$ & $6.0^{\mathrm{a}}$ & $5.6^{\mathrm{a}}$ \\
\hline $25 \%$ & $53.67^{b}$ & $42.57^{\mathrm{a}}$ & $3.88^{\mathrm{a}}$ & $9.8^{\mathrm{a}}$ & $5.2^{\mathrm{a}}$ \\
\hline $50 \%$ & $28.10^{\mathrm{a}}$ & $15.63^{\mathrm{a}}$ & $2.19^{\mathrm{a}}$ & $6.4^{\mathrm{a}}$ & $4.0^{\mathrm{a}}$ \\
\hline $75 \%$ & $32.93^{\mathrm{a}}$ & $27.44^{\mathrm{a}}$ & $4.36^{\mathrm{a}}$ & $5.4^{\mathrm{a}}$ & $3.8^{\mathrm{a}}$ \\
\hline $100 \%$ & $30.07^{\mathrm{a}}$ & $16.80^{\mathrm{a}}$ & $3.22^{\mathrm{a}}$ & $6.2^{\mathrm{a}}$ & $5.2^{\mathrm{a}}$ \\
\hline
\end{tabular}

The results of the normality test of the data obtained show that normal data has a sig value. $0.66>0.05$ so that the Manova test can be continued. Sig value. $<0.05$ was obtained from the Manova test, this indicated that the provision of PGPR had a significant effect on plant dry weight and peanut pod weight. While the homogeneity test using Lavene's test shows the sig value. $>0.05$ so that the further test used is the Bonferroni test. From statistical calculations, there was no significant difference between the weight of pithy pods and the weight of empty pods, between control $(0 \%)$ and treatments $(25 \%, 50 \%, 75 \%$, and $100 \%)$. However, the dry weight of plants is known to have significant differences between control $(0 \%)$ and treatments $(50 \%, 75 \%$, and $100 \%)$ with $25 \%$ treatment.

The plant dry weight statistical test (Table 1) showed that the provision of PGPR with a concentration of $25 \%$ was significantly different from the control $(0 \%)$ and other treatments $(50 \%, 75 \%$, and $100 \%$ ). This significant difference in plant dry weight is due to the bacterial content in PGPR of pioneering lime mining plants that can adapt to calcareous soil growing media and help provide nutrients, especially $\mathrm{N}$ and produce Indole Acetic Acid to increase root growth and canopy of groundnut plants (A. hypogaea L.) var. Tuban. Plant roots and shoots affect plant weight (Nio \& Torey, 2013). Rahni (2012) states that PGPR has a dual role, namely as a provider of nutrition and AIA hormones which are reported to increase the dry weight of maize plants. Bacteria in PGPR can fix nitrogen without symbiosis with roots, but the results of this fixation can be well absorbed by roots (Maulina et al., 2015). The availability of nutrients has an important role in plant growth, one of which is the availability of $\mathrm{N}$ nutrients which can have a significant effect on leaf area (Febrianna et al., 2018). 
The application of various concentrations of PGPR did not significantly affect the weight of pithy pods and the weight of empty pods as well as the number of pithy pods and the number of empty pods (Table 1). The cause of this incident was due to the nutrient content which influenced the formation of the seeds of peanut ( $A$. hypogaea L.) var. Tuban on calcareous soil-plant media has been fulfilled. The average weight of pithy pods in this study ranged from $12.82 \mathrm{~g}$ to $42.57 \mathrm{~g}$ with the mean number of pods ranging from $6 \mathrm{~g}$ to $9.8 \mathrm{~g}$. The pod weight is classified as normal for this peanut variety. According to Kasno \& Harnowo (2015), the weight of the local Tuban peanut variety is around $36 \mathrm{~g} / 50$ pods. The nutrient element that is needed in the formation of pods is calcium $(\mathrm{Ca})$ which is needed for the formation of the gynophore to the cooking of the pods (Rahmianna et al., 2015). Limestone soil originates from limestone source rock and its chemicalphysical properties are influenced by the activity of $\mathrm{CaCO}_{3}$ with very high dissolved calcium (Achmad, 2019).

The Physico-chemical parameters observed were temperature and $\mathrm{pH}$ of the planting medium of ex-mining lime for peanut plants after being applied with indigen PGPR. The average temperature fluctuation observed during 12 WAP is presented in Table 2 which is clarified by Figure 1.

Table 2. The average temperature of the planting medium after various concentrations of PGPR was applied for 12 WA

\begin{tabular}{ccccccccccccc}
\hline \multirow{2}{*}{ Treatment } & \multicolumn{10}{c}{ Week } \\
\cline { 2 - 13 } & $\mathbf{1}$ & $\mathbf{2}$ & $\mathbf{3}$ & $\mathbf{4}$ & $\mathbf{5}$ & $\mathbf{6}$ & $\mathbf{7}$ & $\mathbf{8}$ & $\mathbf{9}$ & $\mathbf{1 0}$ & $\mathbf{1 1}$ & $\mathbf{1 2}$ \\
\hline $0 \%$ & 30.6 & 30.0 & 35.8 & 28.6 & 28.6 & 29.2 & 31.8 & 33.4 & 34.6 & 33.2 & 31.8 & 32.8 \\
$25 \%$ & 31.0 & 30.0 & 36.4 & 29.0 & 29.2 & 29.6 & 31.0 & 34.0 & 35.4 & 33.2 & 32.2 & 32.8 \\
$50 \%$ & 29.8 & 30.0 & 36.2 & 28.6 & 28.6 & 29.8 & 30.2 & 33.6 & 34.6 & 33.0 & 31.6 & 32.2 \\
$75 \%$ & 30.2 & 30.0 & 36.2 & 29.0 & 29.2 & 29.4 & 30.8 & 33.4 & 35.0 & 33.0 & 31.2 & 33.2 \\
$100 \%$ & 30.4 & 30.0 & 35.8 & 29.4 & 29.4 & 29.0 & 31.0 & 33.6 & 34.8 & 32.8 & 31.2 & 32.2 \\
\hline
\end{tabular}

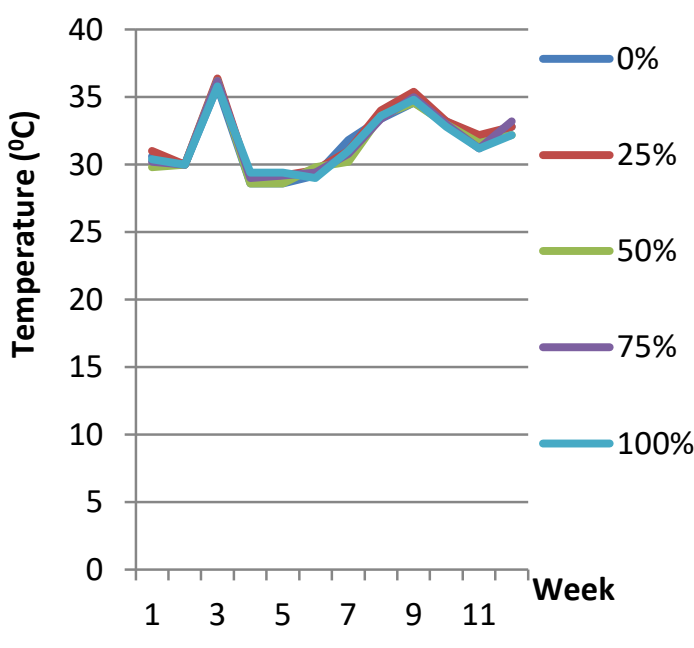

Figure 1. The average temperature of the peanut (A. hypogaea L.) var. Tuban in the calcareous soil with the addition of indigenous PGPR for 12 WAP
From the results of the study, it is known that the average planting medium temperature observations (Table 2 and Figure 1.) ranged from 31.52 to $31.98^{\circ} \mathrm{C}$. The temperature of this planting medium tended to be high because the observation time was carried out during the day starting at 09.00 and finished at 15.00 WIB. The temperature of the soil or the planting medium is influenced by the hot sun and the absorption of heat by the soil, which causes the temperature of the exmining limestone to be higher (Prayudyaningsih \& Sari, 2016).

The average $\mathrm{pH}$ fluctuation of the planting medium in the form of exmining lime for peanuts (A. hypogaea L.) var. Tuban. The addition of PGPR pioneer plants which were observed during 12 WAP is presented in Table 3. which is clarified by Figure 2 . 
Table 3. Average pH of the planting media after applying various concentrations of PGPR for 12 WAP

\begin{tabular}{ccccccccccccc}
\hline \multirow{2}{*}{ Treatment } & \multicolumn{10}{c}{ Week } \\
\cline { 2 - 12 } & $\mathbf{1}$ & $\mathbf{2}$ & $\mathbf{3}$ & $\mathbf{4}$ & $\mathbf{5}$ & $\mathbf{6}$ & $\mathbf{7}$ & $\mathbf{8}$ & $\mathbf{9}$ & $\mathbf{1 0}$ & $\mathbf{1 1}$ & $\mathbf{1 2}$ \\
\hline $0 \%$ & 6.8 & 7.0 & 7.0 & 7.1 & 7.0 & 7.0 & 7.4 & 7.3 & 7.5 & 7.0 & 7.0 & 7.0 \\
$25 \%$ & 7.1 & 7.0 & 7.0 & 7.0 & 7.0 & 7.0 & 7.2 & 7.1 & 7.2 & 7.0 & 7.0 & 7.2 \\
$50 \%$ & 6.9 & 7.0 & 7.0 & 7.1 & 7.0 & 7.0 & 7.3 & 7.1 & 7.5 & 7.0 & 7.0 & 7.2 \\
$75 \%$ & 6.9 & 7.0 & 7.0 & 7.1 & 7.0 & 6.9 & 7.2 & 7.6 & 7.7 & 7.0 & 7.0 & 7.0 \\
$100 \%$ & 7.0 & 7.0 & 7.0 & 6.9 & 7.0 & 6.8 & 6.9 & 7.7 & 7.5 & 7.0 & 7.0 & 7.4 \\
\hline
\end{tabular}

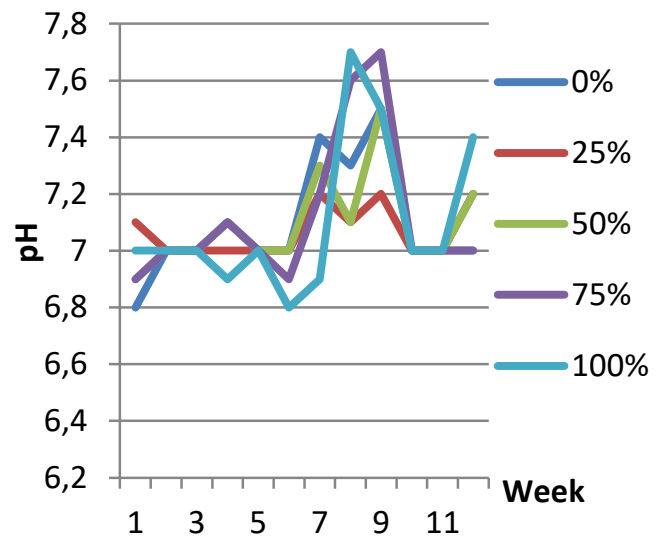

Figure 2. Average pH of peanut $(A$. hypogaea $\mathrm{L}$.) growing media var. Tuban in the form of calcareous soil with the addition of indigen PGPR for 12 WAP

The average $\mathrm{pH}$ of the planting media observed during 12 WAP was neutral (7.07-7.12) as shown in Table 3. This was due to the incubation of PGPR in a phosphate buffer solution in $\mathrm{pH} 7$. The phosphate buffer solution is a neutral solution with a $\mathrm{pH}$ range of 7 . Phosphate buffer solution $\mathrm{pH} 7$ is used as a solvent in the PGPR incubation to maintain the $\mathrm{pH}$ of the microbial intracellular fluid contained in the rhizosphere layer of the former lime mining pioneer plant (Retno, 2008).

The temperature and $\mathrm{pH}$ in this research were analyzed using Manova with the Bonferroni as Post Hoc test. The summary of the Manova statistical test on the effect of giving various concentrations of indigenous PGPR on the temperature and $\mathrm{pH}$ of the planting medium is shown in Table 4.
Table 4. Effect of Indigenous PGPR Application on Temperature and $\mathrm{pH}$ of Calcareous Soil Planting Media

\begin{tabular}{ccc}
\hline Treatment & Temperature & $\mathbf{p H}$ \\
\hline $0 \%$ & $31.73^{\mathrm{a}}$ & $7.09^{\mathrm{a}}$ \\
$25 \%$ & $31.98^{\mathrm{a}}$ & $7.07^{\mathrm{a}}$ \\
$50 \%$ & $31.52^{\mathrm{a}}$ & $7.09^{\mathrm{a}}$ \\
$75 \%$ & $31.72^{\mathrm{a}}$ & $7.12^{\mathrm{a}}$ \\
$100 \%$ & $31.63^{\mathrm{a}}$ & $7.10^{\mathrm{a}}$ \\
\hline
\end{tabular}

The results of the statistical test (Table 4.) show that there is no significant difference between control $(0 \%)$ and treatments $(25 \%, 50 \%, 75 \%$, and $100 \%)$ with soil $\mathrm{pH}$ and soil temperature. This is because the peanut planting area in this study was in the same location and the source of the planting medium comes from the same place, namely the limestone mountains in Leran Wetan Village, Palang District, Tuban Regency, which naturally tends to be neutral in $\mathrm{pH}$. According to Indrawan et al. (2017), planting media in the same location has the same temperature and this temperature is one component of the plant microclimate. Calcareous soils are composed of calcium and magnesium carbonate minerals which have neutral to alkaline $\mathrm{pH}$ characteristics (Achmad, 2019).

\section{Conclusion}

The application of indigenous PGPR for ex-mining lime pioneer plants had a significant effect on the dry weight of peanut (A. hypogaea L.) var. Tuban with the most optimal concentration of 
$25 \%$. As for the yield of peanut pods (A. hypogaea L.) var. Tuban and the physical and chemical characteristics of the planting medium of calcareous soil in the form of temperature and $\mathrm{pH}$, giving indigenous PGPR pioneer ex-mining lime plants did not have a significant effect.

\section{References}

Achmad, A. (2019). Rahasia ekosistem hutan bukit kapur. Firstbox Media.

Andriani, R., Kurniahu, H., \& Sriwulan, S. (2019). Inventarisasi Tumbuhan Pionir Lahan Bekas Tambang Kapur Di Kecamatan Rengel Kabupaten Tuban Jawa Timur. Biotropic: The Journal of Tropical Biology, 3(1), 56-61.

Aryanto, A. (2015). Pertumbuhan dan produksi padi sawah dan gogo dengan pemberian pupuk hayati berbasis bakteri pemacu tumbuh di tanah masam. Jurnal Ilmu Pertanian Indonesia, 20(3), 229235.

Febrianna, M., Prijono, S., \& Kusumarini, N. (2018). Pemanfaatan Pupuk Organik Cair untuk Meningkatkan Serapan Nitrogen serta Pertumbuhan dan Produksi Sawi (Brassica juncea L.) pada Tanah Berpasir. Jurnal Tanah Dan Sumberdaya Lahan, 5(2), 1009-1018.

Hanudin, H., Budiarto, K., \& Marwoto, B. (2018). Potensi Beberapa Mikroba Pemacu Pertumbuhan Tanaman Sebagai Bahan Aktif Pupuk dan Pestisida Hayati. Jurnal Penelitian dan Pengembangan Pertanian, 37(2), 59-70.

Indrawan, R. R., Suryanto, A., \& Soelistyono, R. (2017). Kajian Iklim Mikro terhadap Berbagai Sistem Tanam dan Populasi Tanaman Jagung Manis (Zea mays saccharata Sturt.). Jurnal Produksi Tanaman, 5(1), 92-99.

Kasno, A., \& Harnowo, D. (2015).
Karakteristik Varietas Unggul Kacang Tanah dan Adopsinya oleh Petani. Iptek Tanaman Pangan, 9(1), 13-23.

Kurniahu, H. (2017). The Rhizosphere PGPR Gramineae Application On The Growth Red Ginger (Zingiber officinale Var. Rubrum). Jurnal Pena Sains, 4(2), 133-137.

Kurniahu, H., Sriwulan, S., \& Andriani, R. (2018). Pemberian PGPR Indigen untuk Pertumbuhan Kacang Tanah (Arachis hypogaea L.) Varietas Lokal Tuban pada Media Tanam Bekas Tambang Kapur. Agrovigor: Jurnal Agroekoteknologi, 11(1), 52-57.

Nio, S. A., \& Torey, P. (2013). Karakter Morfologi Akar sebagai Indikator Kekurangan Air pada Tanaman. Jurnal Bios Logos, 3(1), 31-39.

Prayudyaningsih, R., Nursyamsi, N., \& Sari, R. (2015). Advantaging Soil Microorganism On The Rhizosphere Of Tuber Crop Under The Shade Of Community Forest Stand In South Sulawesi. In Prosiding Seminar Nasional Masyarakat Biodiversitas Indonesia. 1. pp. 954-959. https:// doi.org/https://doi.org/10.13057/ps nmbi/m010452.

Prayudyaningsih, R., \& Sari, R. (2016). The application of arbuscular mycorrhizal fungi (AMF) and compost to improve the growth of teak seedlings (Tectona grandis Linn. F.) on limestone post-mining soil. Jurnal Penelitian Kehutanan Wallacea, 5(1), 37-46.

Rahmianna, A. A., Pratiwi, H., \& Harnowo, D. (2015). Budidaya Kacang Tanah. Monogr. Balitkabi. Malang: Balai Penelitian Aneka Kacang dan Umbi. Retrieved from https://balitkabi.litbang.pertanian.g o.id/wp-content/uploads/2015/06/ 9._OK_Anna_OK_133-169-1.pdf. Rahni, N. M. (2012). Efek Fitohormon 
PGPR terhadap Pertumbuhan Tanaman Jagung (Zea mays). CEFARS: Jurnal Agribisnis dan Pengembangan Wilayah, 3(2), 2735.

Retno, I. (2008). Prinsip-prinsip Sains untuk Keperawatan. Jakarta: Erlangga.

Sriwulan, Kurniahu, H., \& Andriani, R. (2018). Pertumbuhan Kacang Tanah (Arachis hypogaea L.) Pada Media Tanam Tanah Bekas Tambang Kapur dan Penambahan PGPR Indigen dalam Kondisi Ternaung. In Prosiding SNasPPM. 3, pp. 229-232.
Wijanarko, A., \& Rahmianna, A. A. (2015). Pemupukan Organik dan Anorganik Pada Kacang Tanah Di Lahan Kering Alfisol. In Prosiding Seminar Hasil Penelitian Tanaman Aneka Kacang dan Umbi. 2015, pp. 4412-4448.

Wuryanta, A. (2019). Zonasi Kerentanan Air Tanah Pada Bentang Alam Karst Dengan Sistem Informasi Geografis Sebagai Dasar Penyusunan Tata Ruang. Seminar Nasional Geomatika, 3, 209-216. https://doi.org/http://dx.doi.org/10. 24895/SNG.2018.3-0.958. 